\title{
NLP PRESUPPOSITIONS AND SUBJECTIVE WELL-BEING: IS THERE ANY ASSOCIATION?
}

\author{
Karsai Xénia \\ Debreceni Egyetem, Pszichológiai Intézet
}

\begin{abstract}
Absztrakt
A bemutatásra kerülő vizsgálat arra a kérdésre keresi a választ, hogy a neurolingvisztikus programozás (NLP) előfeltevéseinek elfogadása összefügghet-e a szubjektív jólléttel, a pszichológiai ellenállóképességgel és az asszertív viselkedéssel. Az eredmények alátámasztják a feltételezést, miszerint az előfeltevésekkel való egyetértés olyan gondolkodásmódot képvisel, amely pozitívan korrelál a szubjektív jóllét és a pszichológiai ellenállóképesség értékeivel. Ugyanakkor az asszertív viselkedéssel való összefüggés nem nyert alátámasztást, ami az elméletben elfogadott elvek és azok gyakorlatba való átültetése közötti inkonzisztenciára utalhat.
\end{abstract}

Kulcsszavak: szubjektív jóllét • pszichológiai ellenállóképesség • asszertív viselkedés - neurolingvisztikus programozás

\begin{abstract}
The study investigates the relationship between one's acceptance of the NLP presuppositions and their level of SWB, psychological immunity and assertive communication. The results prove that the acceptance of NLP presuppositions represents a way of thinking that is positively associated with SWB and it is also positively related to psychological immunity. However, no association was found between the acceptance of the NLP presuppositions and assertive behaviour, which may suggest that conceptual acceptance does not necessarily result in practical realisation.
\end{abstract}

Keywords: subjective well-being - psychological immunity - assertive behaviour • neurolinguistic programming

\section{INTRODUCTION}

There has been an ongoing interest in defining and modelling subjective well-being and also in identifying its determinants, antecedents and consequences (Bradburn, 1969; Diener, 1984; Headey and Wearing, 1990; Dodge, Daly, Huyton and Sanders, 2012; Durayappah, 2011). Most researchers agree that subjec- 
tive well-being is fairly stable over time, which draws attention to the factors forming its stock as described in the dynamic equilibrum model (Headey and Wearing, 1990 ). A line of research examines the effects of social and demographic circumstances such as age, sex, marital status and socio-economic status (Haring, Stock and Okun, 1984; Diener, Sandvik, Seidlitz and Diener, 1993). Other investigators aim at revealing personality-related correlation e.g. personal strivings, value priorities, strength of character and Big 5 correlates (Emmons, 1986; Sagiv and Schwartz, 2000; Emmons and Diener, 1985; Park, Peterson and Seligman, 2004; Hayes and Joseph, 2003). The current study belongs to the latter mentioned line of research and explores whether there is a relationship between a person's way of thinking, more precisely the acceptance of a specific system of thoughts and Subjective Well-Being.

\section{NLP PRESUPPOSITIONS}

NLP covers techniques and practices for improving communication skills and achieving personal development. The methodology is based on modelling the skills of exceptional people and it is claimed that the use of the NLP techniques allows anyone to acquire those skills creating lasting change in one's life. As far as empirical evidence is concerned, examples both supporting and discrediting NLP methodology can be found (Tosey and Mathinson, 2003; Witkowski, 2010). However, this time our interest lies merely in the guiding philosophy that forms the basis of the successful use of the NLP techniques. The presuppositions can be regarded as the central principles of NLP, as its core concepts, as its basic beliefs. As for the aquirement of the desired skills, they have never been claimed to be true or universal. They could be described as a guiding device to assist people in making transitions in their thinking to new forms of perception implicit in the techniques. For the sake of experiencing change in attitudes and behaviour,it is demanded to presuppose them to be true and then act as if they were, indeed.

Taken apart from practical considerations and its implications with NLP, the presuppositions may be treated as a set of ethical principles for life. They represent certain value priorities including the following motivational types of values described in Schwartz's (1992) theory of universals: Self-direction, Stimulation, Universalism, Benevolence, Achievement. Essentially, the current study investigates whether people who find this particular set of values more consistent with their own set of values have a higher level of subjective well-being regardless the causal explanation of this consistency. It may occur that one agrees with the NLP presuppositions simply because of one's personal characteristics or as a result of life experiences. Qualification in NLP was not required when testing the connection and the set of principles were presented without any indication to NLP. 
Given the content and the structure of the NLP presuppositions it may be assumed that they relate to how one copes with changes and difficulties. It implies that the extent to which one agrees with the set of principles covered by the presuppositions is positively associated with one's psychological immunity, therefore this relation has also been tested in the course of the investigation.

Although in the present study the NLP presuppositions are investigated without reference to NLP techniques or NLP at all it seemed to be appropriate to extend the range of the investigation to practical concerns. At this point, our interest lies in exploring the possible behavioural projection of the presuppositions. It is expected that agreement with the presuppositions form a cognitive basis of assertiveness that is meeting challenges with confidence and solving problems in the best and adequate manner. It also implies achieving goals without harming the rights of others and expressing thoughts and feelings in socially justified ways (Peneva and Mavrodiev, 2013).

\section{METHOD}

\section{Participants and procedure}

Ninety-four participants - 74 women (79\%) and 20 men (21\%) - entered the online survey, who were invited through emails and social networking websites. Data were collected anonymously in a 2 weeks period. The survey consisted of four parts as described below. Statistical analyses were performed using R version 3.1.3.

\section{Instruments}

Approval of the NLP presuppositions Since NLP has never been claimed to be an independent theory, its presuppositions have not been empirically tested and their inventory has not been established yet. Their quantity and exact phrasing may vary slightly author by author, however, those differences do not effect their essence and conceptual framework. Qualitative comparison of several approaches resulted in constricting analysis to five lists (Andreas and Faulkner, 2012; Dotz, 2014; Alder, 2002; O'Connor, 2001; Stenger, 2013). Having deleted recurring elements and uniting these lists ended in creating a set of 14 principles, below:

1. Our view of the world is not objective. People are influenced by their feelings and beliefs when they form a view of reality.

2. Past events are unchangeable but we can change our attitude when we evoke them. In this way, people can reduce unpleasant effects and enrich pleasant memories. 
3. If one person can do something, it can be done by anyone else, too, so it is worth giving it a try.

4. People have all the resources they need to bring about change and success.

5. There is no failure, only feedback indicating that another attitude may be more productive in the given situation.

6. Having a great variety of choices in a situation is favourable because it increases the chance of finding the best solution.

7. Our imagination has an influence on achieving our goals just as well as our knowledge and experience. It is easier to realise our wishes if we can imagine them vividly.

8. We are always communicating: our nonverbal behaviour, gestures and face tell what we feel and think even if we do not talk.

9. The meaning of communication is its result. If it is not consistent with our intentions, it may mean that with rephrasing our thoughts a more accurate interpretation should be promoted.

10. People work perfectly. Our thoughts, feelings and actions lead to coherent results.

11. Every behaviour has a positive intention.

12. People make the best choice they can at the time.

13. Mind and body form a system. If we change our physical reactions our feelings and thoughts will change as well.

14. If something does not work, we should try something else. If we always do the same thing, the result will be the same as well.

In the following, each principle was assigned its reciprocal concept thus forming 14 opposing pairs of statements. Participants had to choose in case of each pair the component that reflects better their own beliefs and value priorities. The score value of every positive statement - approving the NLP presuppositions - is 1 , and of every reciprocal statement is o. The number of choices in favour of the NLP presuppositions thus gives the degree of approval, which means possible total scores ranging from o to 14 .

Subjective Well-Being Global life satisfaction was measured with the Satisfaction With Life Scale (SWLS; Diener, Emmons, Larsen and Griffin, 1985). The scale consists of five statements, item scale ranging from 1(strongly disagree) to 7 (strongly agree).

Psychological immunity The Psychological Immune System Inventory (PISI; Oláh, 1996, 2004) consists of 80 items measuring 16 factors (positive thinking, sense of control, sense of coherence, sense of self growth, change and challenge orientation, social monitoring capacity, problem solving capacity, self efficiency, social mobilizing capacity, social creation capacity, synchronicity, goal orientation, impulse control, emotion control and irritability control). Items are scored from 1 (completely does not describe me) to 4 (completely describes me). 
Assertive behaviour The Rathus Assertiveness Schedule (RAS; Rathus, 1973 ) is a 30 -item scale where items are scored from +3 (very much like me) to -3 (very unlike me).

\section{RESULTS}

The Shapiro-Wilks test was performed to test for the normality of each variable. The p-value being lower than 0,05 suggest a deviation from normality in case of two variables, i.e. Subjective Well-Being and Approval of the NLP presuppositions. (Subjective Well-Being: $\mathrm{p}=0,001$; Approval of the NLP presuppositions: $\mathrm{p}=0,02$; Psychological immunity: $\mathrm{p}=0,24$; Assertive behaviour: $\mathrm{p}=0,92$ ). For this reason, non-parametric tests were used to check the hypothesized correlation between the variables (Takács, 2012, Takács, 2016 \& Vargha, 2015).

Approval of the presuppositions Participants score high in approval of the presuppositions with a mean of $10,74(\mathrm{SD}=1,76)$ for the whole sample. Gender differences proved to be significant which is manifested in a mean of 9,85 $(\mathrm{SD}=1,66)$ for men and in a mean of $10,98(\mathrm{SD}=1,72)$ for women. Table 1. presents for each principle the number of participants by acceptance/ refusal.

Table 1. Approval of the presuppositions

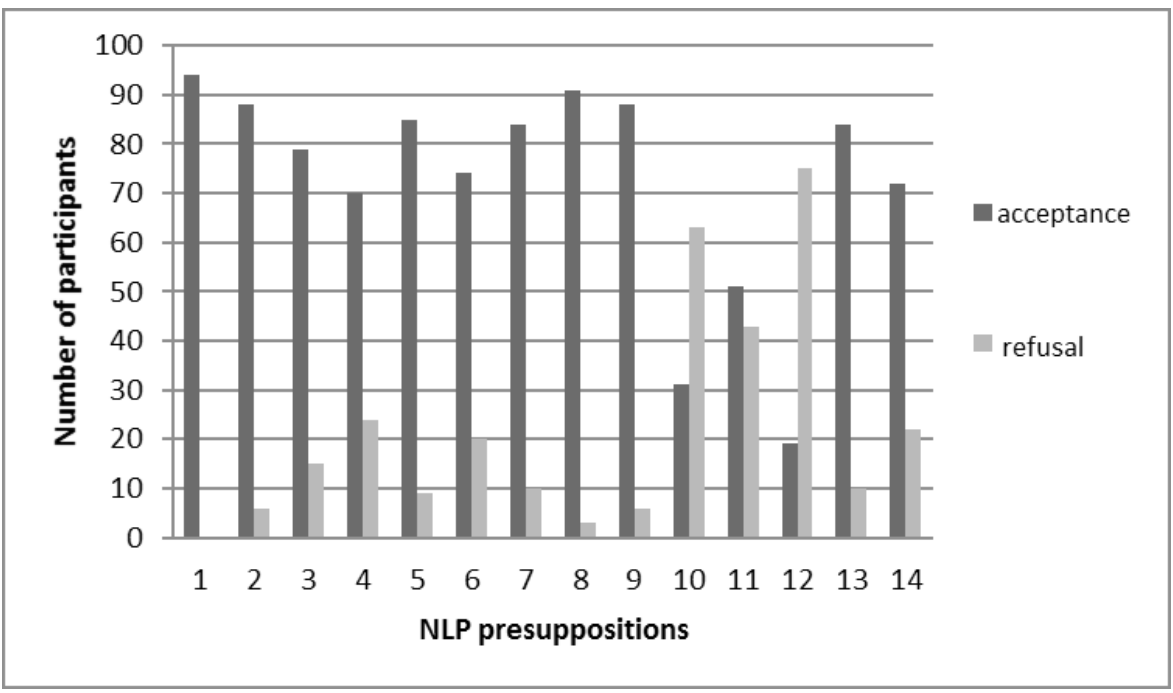

Acceptance exceeds refusal in most cases except for two principles (People work perfectly; People make the best choice). In addition to this, refusal is notably high in one more case (Every behaviour has a positive intention). 
Subjective Well-Being SWLS scores have a mean of 23,59 (SD=6,45) with no significant gender differences $(\mathrm{M}=25,35 ; \mathrm{SD}=6,75$ for men and $\mathrm{M}=23,12 ; \mathrm{SD}=6,32$ for women). The hypothesized positive correlation between subjective well-being and the approval of the presuppositions was significant (rho=0,406; $p<0,01$ ). Taking gender differences into consideration in the approval of the NLP presuppositions implies that for men the same level of subjective well-being correlates with a smaller number of accepted principles.

Psychological immunity PISI scores have a mean of 228,65 (SD=32,29) with no significant gender differences either $(\mathrm{M}=234,5 ; \mathrm{SD}=31,11$ for men and $\mathrm{M}=227,07 ; \mathrm{SD}=32,62$ for women). The expected positive association between PISI scores and agreement with the NLP presuppositions was not strong but it was significant ( $r h o=0,298 ; \mathrm{p}<0,01)$. Table 2 . presents detailed correlation results for PISI subscales.

In order to check whether there is a significant difference between the correlation coefficients of men and women, Fisher transformation was used for each subscale. The results proved to be significant only in case of Impulse control $(p<0,05)$, while for the rest of the subscales it seems that the appearing differences have no real significance.

Assertive behaviour RAS scores have a mean of $12,59(\mathrm{SD}=21,82)$ with no significant gender differences $(M=15,7 ; \mathrm{SD}=23,43$ for men and $\mathrm{M}=11,74 ; \mathrm{SD}=21,45$ for women). In contrast with the expectations, the hypothetical positive correlation between assertive behaviour and the approval of the presuppositions was not supported, there was no evidence for any relation between them $(\mathrm{p}>0,05)$.

\section{CONCLUSIONS}

The present study raised the question whether concordance with a specific system of principles, namely with the presuppositons of NLP, might be associated with an individual's level of Subjective Well-Being, psychological immune capacity and assertive behaviour. As predicted, those subjects who find this particular set of values more consistent with their own set of values have a higher level of Subjective Well-Being.

Findings also support the hypothesized positive correlation between the results of the psychological immune system inventory and the approval of the NLP presuppositions. The NLP presuppositions represent a set of principles reflecting optimism, positive thinking, challenge orientation and respect for others which is manifested in the strength of association with certain PISI subscales.

At the same time, contrary to expectations, there was a lack of correlation between the approval of the NLP presuppositions and assertive behaviour. These findings may allow the interpretation that there is inconsistency between accepting concepts and transforming them into practice. Approaching from the 


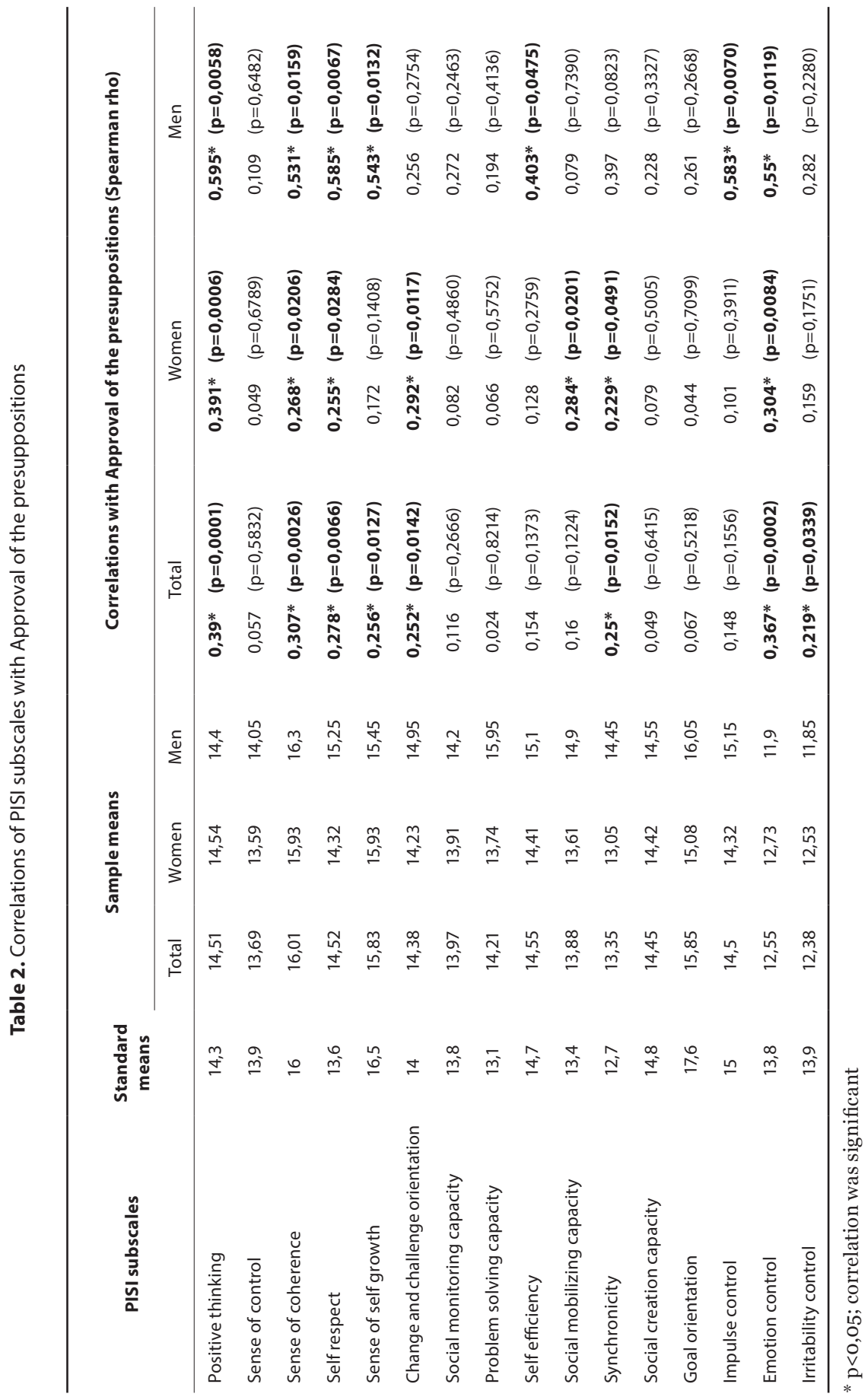


acceptance side of the discrepancy, a possible explanation is that people are likely to emphasize and agree with principles that are important in their social environment without real identification with these values. Focusing on the process of transformation, the above-mentioned inconsistency may be related to the self-determination theory (Ryan and Deci, 2000): for thinking to be reflected in self-determined activity it is required to be associated with more internalized motivation and regulation.

In summary, the findings of the investigation demonstrate the positive relation between Subjective Well-Being and the approval of NLP presuppositions. In order to have a more subtle view of this connection, it would be advisable to take into consideration both lines of research desribed in the introduction and examine the effects of social and demographic circumstances as well. However, in the light of the results it is worth continuing research especially regarding the possibilities of revealing the inconsistency betweeen the conceptual and behavioural aspects. In the present study design, NLP qualification or previous experience with NLP techniques was not included, however it may imply new directions for future research as well.

\section{REFERENCES}

Alder, H. (2002): Handbook of NLP: A Manual for Professional Communicators. Burlington, VT: Gower.

Andreas, S., Faulkner, C. (2012): NLP - A változás te magad légy! Libri, Budapest.

Bradburn, N. (1969): The structure of psychological well-being. Chicago: Aldine.

Diener, E. (1984): Subjective well-being. Psychological Bulletin, 95, 542-575.

Diener, E., Emmons, R.A., Larsen, R.J., Griffin, S. (1985): The Satisfaction With Life Scale, Journal of Personal Assessment, 49, 71-75.

Diener, E., Sandvik, E., Seidlitz, L. and Diener, M. (1993): The relationship between income and subjective well-being: Realtive or absolute? Social Indicators Research, 28, 195-223.

Dodge, R., Daly, A.P., Huyton, J., Sanders, L.D. (2012): The challenge of defining well-being. International Journal of Wellbeing, 2, 222-235.

Dotz, T. (2014): The Top 13 Original Major Presuppositions of NLP Defined. NLP Comprehensive. letöltve: 2015.03.05. http://www.nlpco.com/2014/10/presuppositions-of-nlp/\#axzz3UTiWKR8g

Durayappah, A. (2011): The 3P model: A general theory of subjective well-being. Journal of Happiness Studies, 12, 681-716.

Emmons, R.A. (1986): Personal strivings: An approach to personality and subjective well-being. Journal of Personality and Social Psychology, 51, 1058-1068.

Emmons, R.A., Diener, E. (1985): Personality correlates of subjective well-being. Personality and Social Psychology Bulletin, 11, 89-97.

Haring, M.J., Stock, W.A., Okun, M.A. (1984): A research synthesis of gender and social class as correlates of subjective well-being. Human Relations, 37, 645-657. 
Hayes, N., Joseph, S. (2003): Big 5 correlates of three measures of subjective well-being. Personality and Individual Differences, 34, 723-727.

Headey, B.W., Wearing, A.J. (1991): Subjective well-being: a stocks and flows framework. In: Strack, F., Argyle, M, Schwartz, N. (szerk.): Subjective wellbeing - An interdisciplinary perspective. Oxford: Pergamon Press. 49-76.

O’Connor, J. (2001): The NLP Workbook: A Practical Guide to Achieving the Results You Want. London: Element.

Oláh A. (1996): Psychological immune system: An integrated structure of coping potential dimensions. Paper presented at the 9th conference of the European Health Psychology Society, Bergen, Norway, 1996.

Oláh A. (2000): Health protective and health promoting resources in personality: A framework for the measurement of the psychological immune system. Paper presented at the First International Positive Psychology Summit, Washington DC, 2002.

Park, N., Peterson, C., Seligman, M.E.P. (2004): Strength of character and well-being. Journal of Social and Clinical Psychology, 23, 603-619.

Peneva, I., Mavrodiev, S. (2013): A historical approach to assertiveness. Psychological Thought, 6, 3-26.

Rathus, S.A: (1973): A 30-item schedule for assessing assertive behavior. Behavior Therapy, 4, 398406.

Ryan, R. M., Deci, E.L. (2000): Self-determination theory and the facilitation of intrinsic motivation, social development and well-being. American Psychology, 55 (1), 68-78.

Sagiv, L., Schwartz S.H. (2000): Value priorities and subjective well-being: direct relations and congruity affects. European Journal of Social Psychology, 30 (2), 177-198.

Schwartz, S. H. (1992): Universals in the content and structures of values: Theoretical advances and empirical test sin 20 countries. Advances in Experimental Social Psychology, 25, 1-65.

Stenger Gy. (2013): A változás müvészete. NLP alapok alapja. NLP Akadémia, Budapest.

Tosey, P., Mathinson, J. (2003): Neuro-linguistic programming and learning theory: A response. Curriculum Journal, 14, 361-378.

Takács, Sz. (2012): Érzékenységvizsgálatok a statisztikai eljárásokban, Alkalmazott Matematikai Lapok, 29, 67-100.

Takács, Sz. (2016): Bevezetés a matematikai statisztikába, elmélet és gyakorlat, Antarész Kiadó, Budapest.

Vargha, A. (2015): Matematikai Statisztika, Pólya Kiadó, Budapest.

Witkowski, T. (2010): Thirty-Five Years of Research on Neuro-Linguistic Programming. NLP Research Data Base. State of the Art or Pseudoscientific Decoration? Polish Psychological Bulletin, $41,(2), 58-66 .^{*}$ 